Egyptian Journal of Aquatic Biology \& Fisheries

Zoology Department, Faculty of Science,

Ain Shams University, Cairo, Egypt.

ISSN $1110-6131$

Vol. 23(4): $669-683$ (2019)

www.ejabf.journals.ekb.eg

\title{
Characterization and Bioremediation potential of marine psychrotolerant Pseudomonas spp. isolated from the Mediterranean Sea, Egypt.
}

\author{
Hanan M. Abd-Elnaby ${ }^{1}$, Gehan M. Abou-Elela ${ }^{1}$, Halla Hussein ${ }^{1}$, \\ Hanan A. Ghozlan ${ }^{2}$ and Soraya A. Sabry ${ }^{2}$ \\ 1- National Institute of Oceanography and Fisheries, Microbiology Laboratory, \\ Environmental Division, El- Anfushy, KayetBay, Alexandria, Egypt. \\ 2- Alexandria University, Faculty of Science, Botany \& Microbiology \\ Department, 21511 Alexandria, Egypt. \\ *E-mail address: hananabdelnaby1@gmail.com
}

\section{ARTICLE INFO}

\section{Article History:}

Received: Aug. 23, 2019

Accepted: Oct. 26, 2019

Online: Nov. 2019

\section{Keywords:}

Psychrotolerant

Pseudomonas sp.

Mediterranean Sea

Genotype

heavy metals

azo-dyes
Fourteen psychrotolerant Pseudomonas strains were isolated from seawater and sediments in the Mediterranean Sea, Egypt, using culturedependent techniques. Genotypic characterization for the fourteen strains was performed using $16 \mathrm{~S}$ rDNA sequence analysis. The Pseudomonas strains were screened for some physiological, and biochemical characters, also resistance to some antibiotics and heavy metals were tested. Moreover, heavy metals bioaccumulation and azo-dyes removal were estimated. All tested Pseudomonas strains were able to resist and accumulate several metals $\left(\mathrm{Pb}^{2}+, \mathrm{Cu}^{2+}\right.$ and $\left.\mathrm{Cd}^{2+}\right)$ with variable degrees, depending on bacterial strains and metal ion species. The highest tolerance (MICs) was observed with lead ions as all strains grew in presence of 750-800 ppm of lead, also, lead ions were easier to be bioaccumulate than the other metals, while cadmium bioaccumulation was relatively low with respect to the other two metals. Pseudomonas sp. H69A was the most potent strain in accumulation of the different metals. It supports the highest accumulated values of lead and cupper (2.95 and $1.837 \mathrm{mg} / \mathrm{g}$ fresh cells, respectively).The Pseudomonas strains were monitored for their ability to decolorize three different azo-dyes (fast orange, methanil yellow and acid fast red). All Pseudomonas strains achieved powerfull decolorization activity with the tested dyes. The maximum decolorization activities were recorded in fast orange. Pseudmonas sp. $\mathrm{H} 26 \mathrm{~S}$ recorded the highest decolorization percentages $(91 \%)$ with fast orange and their biosorption capacity was 4.8 $\mathrm{mg} / \mathrm{g}$.

\section{INTRODUCTION}

Marine ecosystem has a higher diversity of living organisms compared to the land that provides numerous resources to human societies (Hill and Fenical, 2010), and the marine microorganisms are highly abundant in nature. It is realistic to assume that we know less than $0.1 \%$, probably only $0.01 \%$ (Simon and Daniel, 2009) of all microbes in the oceans. Marine microorganisms inhabit all kinds of available niches. They can be isolated from the marine water, sediments, and mangroves associated with the marine habitats, normal flora of the marine organisms, and deep sea hydrothermal vents (Yang et al., 2013; Zhang et al., 2013). Cold adapted organisms, psychrophiles and psychrotrophs, inhabit both terrestrial and aquatic environments in 
polar and alpine regions, in the bulk of the ocean, in shallow subterranean regions, in the upper atmosphere, in refrigerated environments, and on plants and animals living in cold regions (Margesin et al., 2007). Psychrotolerant organisms grow well at temperatures close to the freezing point of water, but have the fastest growth rates above $20^{\circ} \mathrm{C}$ (Margesin et al., 2007; Orellana-Saez et al., 2019), whereas psychrophilic organisms grow faster at a temperature of $15^{\circ} \mathrm{C}$ or lower, but are unable to grow above $20^{\circ} \mathrm{C}$ (Margesin et al., 2007).

Both physical and chemical factors affect the distribution and activity of different microbial types (Shimshon and Rita, 2005). Cold-adapted organisms have successfully evolved features, genotypic and/or phenotypic, to surmount the negative effects of low temperatures and to enable growth in these extreme environments (Salvino et. al., 2006). They contribute essentially to the processes of nutrient turnover, biomass production, and litter decomposition in cold ecosystems. There is evidence of a wide range of metabolic activities in cold habitats, e.g., nitrogen fixation, photosynthesis, methanogenesis, and degradation of natural or xenobiotic organic compounds such as proteins, carbohydrates, lignin, and hydrocarbons (Trotsenko and Khmelenina, 2005).

Until now, about 100 species of the genus Pseudomonas have been reported from various habitats including Antarctica (Vásquez-Ponce, et al., 2018; Yarzabal et al., 2019). Kriss et al., (1976) were the first to report the existence of Pseudomonas species in Antarctica.

The biotechnological applications of psychrotolerant and psychrophilic bacteria have been studied by Huston (2007). Psychrotolerant bacteria are great value for bioremediation of contaminated ecosystems in Antarctica. Psychrotolerant bacteria have the ability to maintain activity under the extreme conditions of the polar ecosystems (Paniker et al., 2006).

The extent of cold habitats is decreasing due to global warming thus affecting the evolution of mesophilic bacteria. The extreme biotechnological importance of cold-adapted bacteria along with their essential role in biogeochemical cycles (Feller and Gerday, 2003) emphasizes the importance of understanding to what extent these bacteria can adapt to ecosystems warming. The research of cold-adapted bacteria in temperate ecosystems will add to the knowledge about this topic (Azevedo et al., 2013).

In a previous work (Abd-Elnaby et al., 2016), reported the isolation and identification of Psychrobcter species from work Mediterranean Sea, Egypt. The present work aimed to throw some light on the characterization of Pseudomonas species and their potentiality in metal accumulation and azo dye decolorization

\section{MATERIALS AND METHODS}

\section{Bacterial strains}

Fourteen Pseudomonas strains used in the present study were isolated from Mediterranean Sea, Egypt, using culture dependent techniques. They were able to grow over a temperature range $\left(5\right.$ to $\left.30^{\circ} \mathrm{C}\right)$ showing good growth at $5^{\circ} \mathrm{C}$.

\section{Media}

Nutrient agar (Oxoid LTD, England) and tryptone yeast extract were used for isolation and growth of the isolated bacteria. Media were prepared with aged seawater and distilled water $(1: 1, \mathrm{v} / \mathrm{v})$. Tryptone yeast extract contained (g/l): Tryptone, 5.0; yeast extract, 2.5; glucose, 1.0; dipotassium hydrogen orthophosphate, 0.2 and 
magnesium sulfate, 0.05. For solid medium $15 \mathrm{~g} / \mathrm{l}$ agar was added (Lyudmila et al., 2002).

\section{Isolation of bacteria}

Samples of water and sediment collected from different sites along the Mediterranean coast were plated on nutrient agar plates and incubated at different temperatures to select those showing psychrophilicity.

\section{Bacterial identification}

The bacterial isolates were cultured in tryptone yeast extract medium overnight and the genomic DNAs were extracted with the genomic DNA extraction protocol of GeneJET genomic DNA Purification Kit (Fermentas). The PCR clean-up of the PCR product was performed using GeneJETTM PCR Purification Kit (Fermentas) at Sigma Scientific Services Company, Egypt. The sequencing of the PCR product was made by the GATC Company using ABI 3730xl DNA sequencer with universal primers (16S 27F and 16S 1492R), (5'-AGAGTTTGATCCTGGCTCAG-3' and 5'GGT TACCTTGTTACGACTT-3'). Genotypic characterization was performed using $16 \mathrm{~S}$ sequence analysis. Multiple alignments with sequences of the most closely related members and calculations of levels of sequence similarity were carried out using BioEdit (software version 7) (Hall, 1999). Sequences of rRNA genes, for comparison, were obtained from the National Center for Biotechnology Information database.

\section{Phenotypic characterization}

The characters of the Pseudomonas strains were studied following the standard microbiological methods as reported in Bergey's Manual of Systematic Microbiology (Holt et al., 2005). Gram reaction, colony morphology, vegetative cell and spore characteristics were tested. Also, production of degradative enzymes and antibiotic sensitivity were tested (Finegold and Martin, 1982).

\section{Growth measurement}

Growth patterns of Pseudomonas strains were tested by allowing cells to grow on tryptone medium at different temperatures $\left(5,12,20\right.$ and $\left.30^{\circ} \mathrm{C}\right)$. Growth of the Pseudomonas strains were monitored by measuring the optical density (OD) of cultures using Spectrophotometer, Model (SP-300) Optima, at wavelength $550 \mathrm{~nm}$ using the medium as blank.

\section{Bioaccumulation of heavy metal}

\section{Preparation of heavy metal solutions}

Stock solutions of chloride salts of zinc, nickel, cadmium and lead in addition to copper sulfate were individually added in equivalent weights to di-ionized water to final concentration of 50-400 ppm for $\mathrm{Zn}^{2+}, \mathrm{Ni}^{2+}, \mathrm{Cd}^{2+}$, and $\mathrm{Cu}^{2+}$ and 10-2000 ppm for $\mathrm{Pb}^{2+}$. Solutions were sterilized by filtration through $0.22 \mu \mathrm{m}$ Millipore bacterial membrane filters (Forbes et al., 1998).

\section{Determination of the minimal inhibitory concentrations (MICs)}

Agar plates supplemented with different concentrations of each metal cations were prepared and dried at $37{ }^{\circ} \mathrm{C}$ for $30 \mathrm{~min}$. Plates were then spot-inoculated with the tested organisms and incubated for 2 days (Mergeay et al.,1985). Plates containing media without metals were used as controls. The MICs are measured as the lowest concentration of the metal ion preventing bacterial growth (Sabry et al., 1997).

\section{Metal bioaccumulation assay}

For metal bioaccumulation studies, aliquots $(0.05 \mathrm{~g})$ of fresh bacterial biomass were placed in $100 \mathrm{ml} \mathrm{screw}$-caped tubes containing $50 \mathrm{ml}$ of metals solutions with a known initial concentration. Bacterial cells were then kept in contact with the metal solution in a shaker incubator at $120 \mathrm{rpm}$ for $1 \mathrm{~h}$. For the estimation of the residual 
metal ions, the metal biomass suspensions were centrifuged at $7000 \mathrm{rpm}$ for $20 \mathrm{~min}$ and the supernatants were (in most cases) diluted by deionized water to a final concentration of $1 / 10$, then submitted to instrumental analysis using an Atomic Absorption Spectrophotometer (Shimadzu -AA-6800). Bioaccumulation of metals ions (q) is calculated according to the following equation:

Metal bioaccumulation $(\mathrm{q})=\mathrm{V}(\mathrm{IC}-\mathrm{FC}) / \mathrm{w}$

where $\mathrm{V}$, volume of reaction (1); IC, initial metal concentration(mg/l); FC, final metal concentration (mg/l); and $\mathrm{W}$, total biomass (g), (Abd-Elnaby et al., 2011).

\section{Decolorization of dyes}

Stock solutions of dye were prepared in water and sterilized at $121{ }^{\circ} \mathrm{C}$ for 15 min, $1 \mathrm{ml}$ of dye solution contains $1.5 \mathrm{mg}$ dye/l. The strains were monitored for their capacity to decolorize 3 different azo-dyes (fast orange, methanil yellow and acid fast red). The experiment was conducted according to El-Ahwany (2008). Each bacterium was grown in $250 \mathrm{ml}$ Erlenmeyer flask containing $50 \mathrm{ml}$ of tryptone yeast extract medium. The flask was inoculated from a pre-culture of the same organism and incubated at $30{ }^{\circ} \mathrm{C}$ shacked till late stationary phase $\left(\mathrm{OD}_{550} 1.0\right)$. Cell biomass $(0.3$ $\mathrm{mg}$ ) was transferred to a test tube containing $1 \mathrm{ml}$ of dye solution $\left(15 \times 10^{-4} \mathrm{~g}\right.$ dye/l). Tubes containing dye solutions and biomass were shacked for $24 \mathrm{~h}$, followed by centrifugation to remove cells. The residual dye concentration was measured in the clear supernatants. The spectral profiles as well as absorbance values of individual dyes at their $\mathrm{k}_{\max }$ were monitored using spectrophotometer. Control experiments were carried under similar conditions without biomass addition. All experiments were carried out in duplicates and the results are the mean value. Decolorization percentage was calculated as follows:

Decolorization\% $=\left(\mathrm{C}_{0}-\mathrm{C}_{\mathrm{e}}\right) / \mathrm{C}_{0} \times 100$

where $\mathrm{Co}=$ Initial absorbance reading before decolorization; and $\mathrm{Ce}=$ final absorbance reading after decolorization.

Biosorption capacity by cells $(\mathrm{mg} / \mathrm{g})=$ concentration of dye biosorbed $/ \mathrm{mg}$ biomass

The concentrations of the residual dyes in the supernatants were determined using a standard curve. All results are the mean of replicates.

\section{RESULTS AND DISCUSSION}

Fourteen bacterial isolates showing good growth at $5^{\circ} \mathrm{C}$ were subjected to identification by molecular tools. DNA sequences were deposited in Genbank. Accession number, sequence homology and similarity percent to closest strains are as given in Table 1. Strains showed similarity percent to different Pseudomonas 99\% and were this assigned as members of Genus Pseudomonas, Gamma proteobacteria. Five strains (H26S, H69A, H20S, H20 and H45A) were isolated from sea water of Alexandria Eastern Harbor, three (H73, H50 and H49) from sediments of Alexandria Eastern Harbor, three (H60, H63A and H44) from Abu-Qir sediments, two (H67 and H67S) from Rashid sea water one strain.(H64) from sediments of Rashid.

Numerous psychrophilic and psychrotolerant Pseudomonas strains have been isolated from Antarctica, (Reddy et al., 2004; Ma et al., 2006; Bozal et al., 2007, Orellana-Saez et al., 2019, Yarzabal et al., 2019, Divya et al., 2019). 
Table 1: Pseudomonas strains, accession numbers and similarity percentage to nearest neighbors.

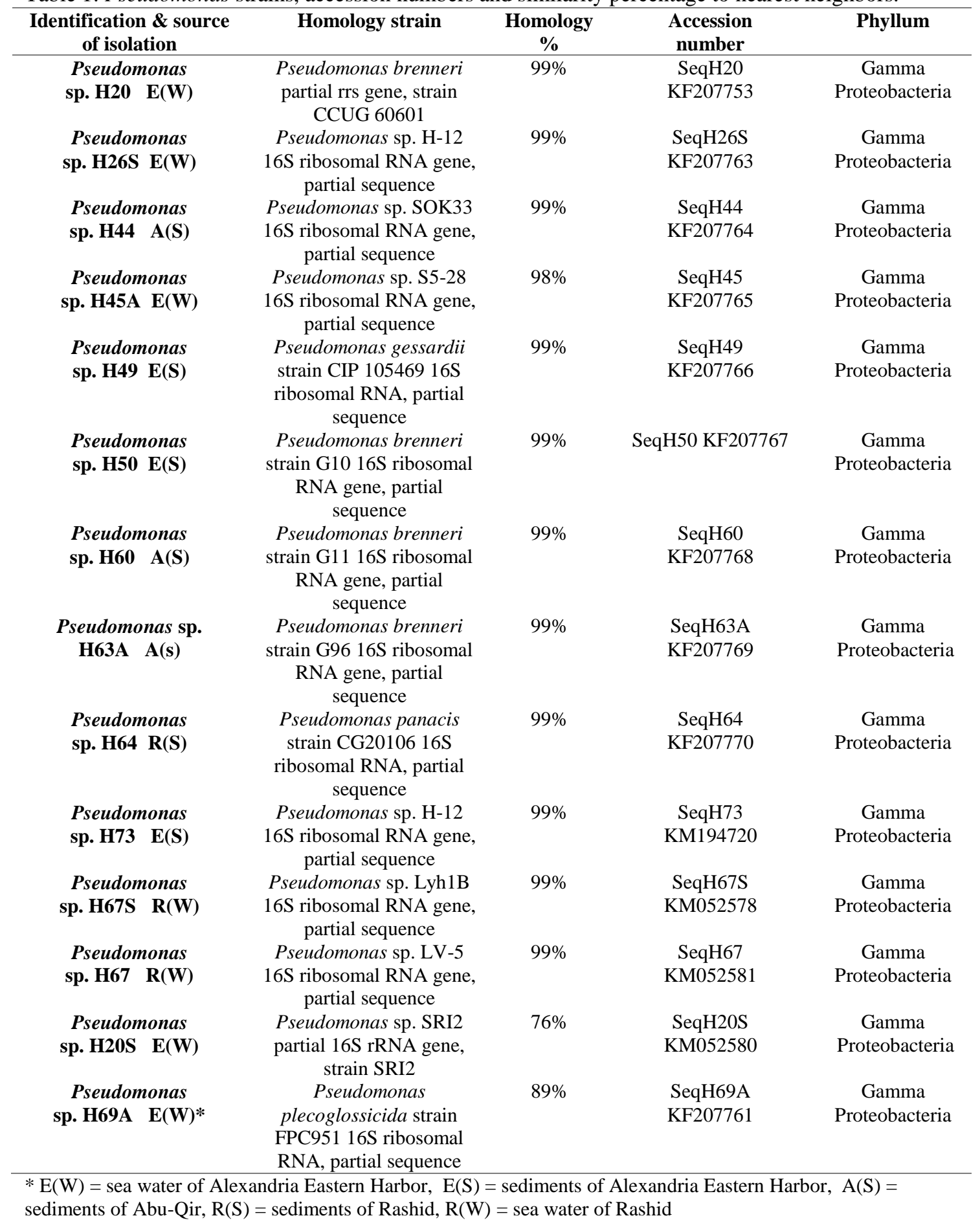

\section{Phenotypic characterization}

The Pseudomonas strains were screened for tolerance to a range of temperatures, salinities and $\mathrm{pH}$, in addition to some physiological and biochemical characterization (Table 2).

To understand these microorganisms' role in this extreme environment, the characterization and description of new species is vital. Vásquez-Ponce et al. (2018) investigated the Phylogenetic and phenotypic analysis identification of three probable novels Pseudomonas species isolated on King George Island, South Shetland, Antarctica. 
Table 2: Phenotypic characteristics of Pseudomonas strains

\begin{tabular}{|c|c|c|c|c|c|c|c|c|c|c|c|c|c|c|c|}
\hline $\begin{array}{l}\text { Characterstics } \\
\text { features }\end{array}$ & 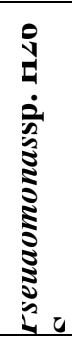 & 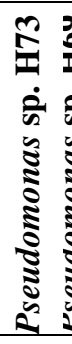 & 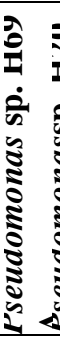 & 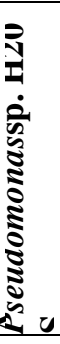 & 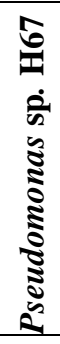 & 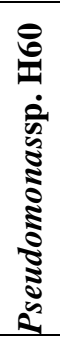 & 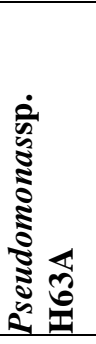 & 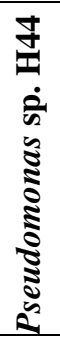 & 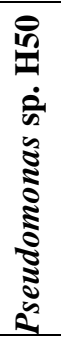 & 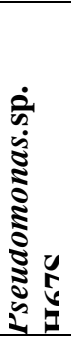 & 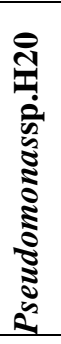 & 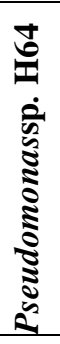 & 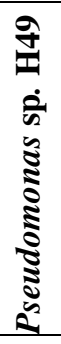 & 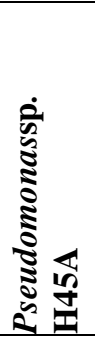 & 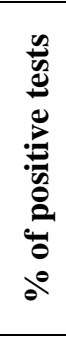 \\
\hline \multicolumn{16}{|c|}{ Morphological characters } \\
\hline \multicolumn{16}{|l|}{ Colony Color } \\
\hline Cream & + & + & + & + & + & + & + & + & + & - & + & - & - & + & 78 \\
\hline White & - & - & - & - & - & - & - & - & - & + & - & - & + & - & 14 \\
\hline Orange & - & - & - & - & - & - & - & - & - & - & - & + & - & - & 7 \\
\hline \multicolumn{16}{|l|}{ Cell shape } \\
\hline Rods & + & + & + & + & + & + & + & + & + & + & + & - & + & + & 93 \\
\hline Cocci & - & - & - & - & - & - & - & - & - & - & - & - & - & - & 0 \\
\hline Coccobacilli & - & - & - & - & - & - & - & - & - & - & - & + & - & - & 7 \\
\hline \multicolumn{16}{|l|}{ Physiological tests } \\
\hline Catalase production & + & + & + & + & + & + & + & + & + & + & + & + & + & + & 100 \\
\hline Oxidase production & + & + & + & + & + & + & + & + & + & + & + & + & + & + & 100 \\
\hline Nitrate reduction & - & + & + & + & - & + & + & + & + & - & - & + & + & - & 64 \\
\hline Urease production & - & + & + & + & - & - & - & - & + & - & - & + & - & - & 35 \\
\hline $\mathrm{H}_{2} \mathrm{~S}$ production & - & - & - & - & - & - & - & - & - & - & - & - & - & - & 0 \\
\hline \multicolumn{16}{|c|}{ Growth at different temp. $\left({ }^{\circ} \mathrm{C}\right)$} \\
\hline $5-30$ & + & + & + & + & + & + & + & + & + & + & + & + & + & + & 100 \\
\hline 40 & + & + & + & + & + & + & - & - & + & + & + & + & - & + & 78 \\
\hline 45 & - & - & - & - & - & - & - & - & - & - & - & - & - & - & 0 \\
\hline \multicolumn{16}{|l|}{ Growth at $\mathrm{pH}$} \\
\hline $5-9$ & + & + & + & + & + & + & + & + & + & + & + & + & + & + & 100 \\
\hline \multicolumn{16}{|c|}{ Growth in presence of $\mathrm{NaCl}(\%)$} \\
\hline $4-7$ & + & + & + & + & + & + & + & + & + & + & + & + & + & + & 100 \\
\hline $9-13$ & - & - & + & - & - & + & - & + & + & - & - & + & + & + & 50 \\
\hline
\end{tabular}

\section{Production of degradative enzymes}

The ability of Pseudomonas strains to secrete six different extra-cellular hydrolytic enzymes was tested. They produced one or more hydrolytic enzymes, chitinase being the one secreted by most strains (100\%). Lipase $(64 \%)$, protease $(64 \%)$ and amylase $(50 \%)$ were moderate in prevalence (Table 3 ).

Until now, researchers have found a wide range of marine microorganisms including Psychrobacter and Pseudomonas that can produce degradative enzymes (Zhang and Kim, 2010).

\section{Sensitivity to antibiotics}

The variability in antibiotic resistance profiles could indicate important strainlevel. The antibiotic's different patterns susceptibility would suggest strain-level differences in accessory or antibiotic-resistance genes either encoded on plasmids, within the genome, or transposons in the bacterial strains (Babaeekhou et al., 2018; Pang et al., 2019).

In the present study, sensitivity of Pseudomonas strains to various antibiotics

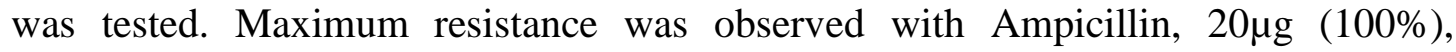


followed by ampicillin, $10 \mu \mathrm{g}$ and Ceftriaxone, 30 $\mathrm{g}$ (93\%). Occurrence of antibiotic resistance were extremely low with cefoperazone, $5 \mu \mathrm{g}(29 \%)$, (Table 4). The data in the present study was in partial agreement with those reported by Reddy et al. (2004).

Table 3: Production of degradative enzymes by Pseudomonas strains.

\begin{tabular}{|c|c|c|c|c|c|c|c|c|c|c|c|c|c|c|c|}
\hline Degradation of & 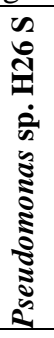 & 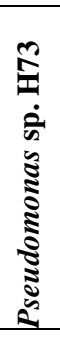 & 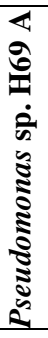 & 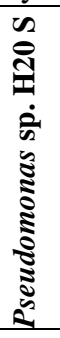 & 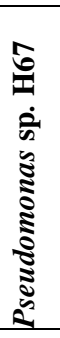 & 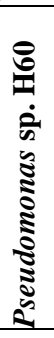 & 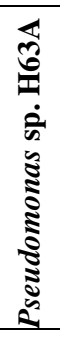 & 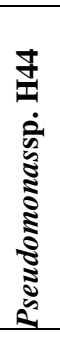 & 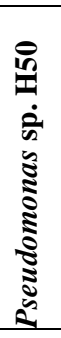 & 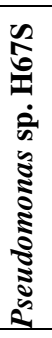 & 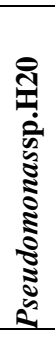 & 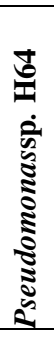 & 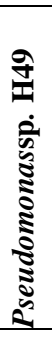 & 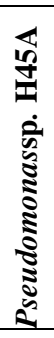 & 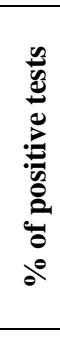 \\
\hline \multicolumn{16}{|l|}{ Starch } \\
\hline $5^{\circ} \mathrm{C}$ & + & + & + & - & + & - & + & - & - & + & - & + & - & - & 50 \\
\hline $10^{\circ} \mathrm{C}$ & + & + & + & - & + & - & + & - & - & + & - & + & - & - & 50 \\
\hline $20^{\circ} \mathrm{C}$ & - & + & - & - & - & - & - & - & - & + & - & - & - & - & 14 \\
\hline \multicolumn{16}{|l|}{ Gelatin } \\
\hline $5-20^{\circ} \mathrm{C}$ & - & + & - & + & + & - & + & - & + & + & - & + & + & + & 64 \\
\hline \multicolumn{16}{|l|}{ Chitin } \\
\hline $5-10^{\circ} \mathrm{C}$ & + & + & + & + & + & + & + & + & + & + & + & + & + & + & 100 \\
\hline $20^{\circ} \mathrm{C}$ & + & + & + & + & - & + & + & + & + & + & + & + & - & + & 85 \\
\hline \multicolumn{16}{|l|}{ Tween 20} \\
\hline $5-10^{\circ} \mathrm{C}$ & - & - & - & - & - & - & - & + & - & - & - & - & - & + & 14 \\
\hline $20{ }^{\circ} \mathrm{C}$ & - & + & - & - & - & - & - & - & - & - & - & - & - & + & 14 \\
\hline \multicolumn{16}{|l|}{ Tween 80} \\
\hline $5-10^{\circ} \mathrm{C}$ & + & + & + & + & - & + & - & + & + & - & + & + & - & - & 64 \\
\hline $20{ }^{\circ} \mathrm{C}$ & + & + & + & + & - & - & + & - & + & - & + & + & + & - & 64 \\
\hline \multicolumn{16}{|l|}{ Skim milk } \\
\hline $5^{\circ} \mathrm{C}$ & - & - & + & - & - & - & - & - & - & - & - & - & - & - & 7 \\
\hline $10^{\circ} \mathrm{C}$ & - & - & + & + & - & - & - & + & + & - & - & + & - & - & 35 \\
\hline $20^{\circ} \mathrm{C}$ & + & - & + & + & - & - & + & + & + & - & + & + & + & - & 64 \\
\hline
\end{tabular}

Table 4: Sensitivity of Pseudomonas strains to some antibiotics

\begin{tabular}{|c|c|c|c|c|c|c|c|c|c|c|c|c|c|c|c|}
\hline Antibiotics $(\mu \mathrm{g})$ & 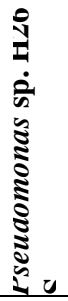 & 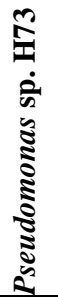 & 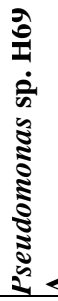 & 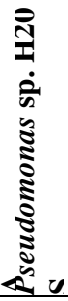 & 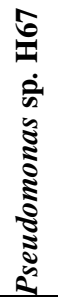 & 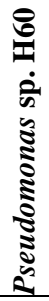 & 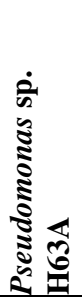 & 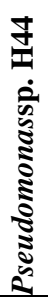 & 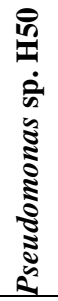 & 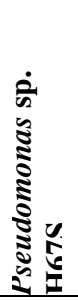 & 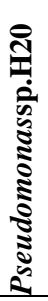 & 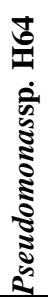 & 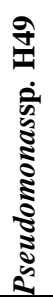 & 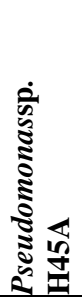 & 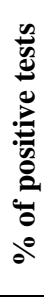 \\
\hline
\end{tabular}

Amikacin, 30

Ceftazidime, 30

Cefoperazone, 5

Ampicillin, 10

Ampicillin, 20

Amipenem, 10

Rifampicin, 30

Doxycycline, 30

Ceftriaxone, 30

$\begin{array}{ccccccccccccccc}- & + & + & - & + & - & + & + & - & + & + & - & + & - & 57 \\ - & + & + & + & + & + & + & + & + & + & + & - & + & + & 86 \\ - & + & - & + & + & - & + & - & - & - & - & - & - & - & 29 \\ + & + & + & + & - & + & + & + & + & + & + & + & + & + & 93 \\ + & + & + & + & + & + & + & + & + & + & + & + & + & + & 100 \\ - & + & - & - & - & + & + & - & + & - & - & - & + & - & 35 \\ - & + & - & - & + & + & + & + & + & + & + & + & + & + & 78 \\ + & + & + & + & - & + & + & + & + & + & + & - & + & + & 86 \\ - & + & + & + & + & + & + & + & + & + & + & + & + & + & 93 \\ - & + & + & + & + & + & + & + & - & + & + & + & + & + & 86\end{array}$




\section{Growth of Pseudomonas strains at different temperatures}

Almost a similar pattern of growth was observed for all Pseudomonas strains as shown in Fig. 1. All Pseudomonas strains grew at the temperature range tested. It is noticeable that no lag phase was observed except for 4 strains (H49, H50, H67 and $\mathrm{H} 20 \mathrm{~S}$ ). It is worth mentioning that growth in cultures incubated at 5 and $10^{\circ} \mathrm{C}$ for 10 days reached the similar values of those incubated at 20 and $30{ }^{\circ} \mathrm{C}$ for 10 days. At these temperatures growth rate was higher compared to that at 5 and $10{ }^{\circ} \mathrm{C}$.

Psychrotolerant bacteria grow well at temperatures near the freezing point of water, but the rate of growth increases at temperature above $20{ }^{\circ} \mathrm{C}$ (Margesin et al., 2007; Orellana-Saez et al., 2019). Bakermans et al. (2006) reported that facultative psychrotolerant or cold adapted bacteria such as Psychrobacter cryohalolentis can grow in temperature ranges from 10 to $30{ }^{\circ} \mathrm{C}$. Also Bozal et al., (2007) isolated two psychrotolerant stains namely Pseudomonas peli and Pseudomonas anguilliseptica, these two psychrotolerant strains grew between -4 and $30^{\circ} \mathrm{C}$.

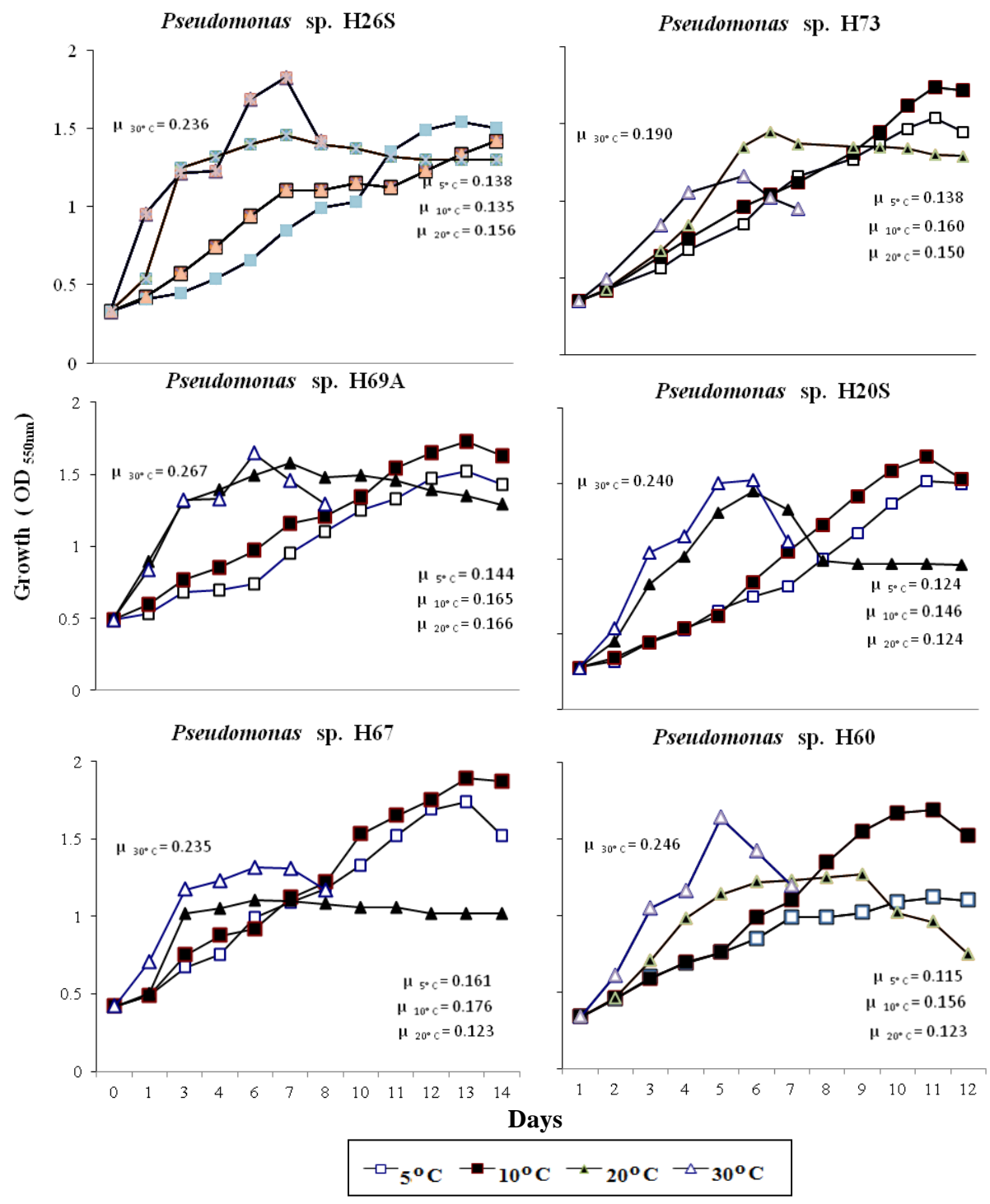

Fig. 1. Growth of Pseudomonas strains on tryptone yeast extract medium at different temperatures 


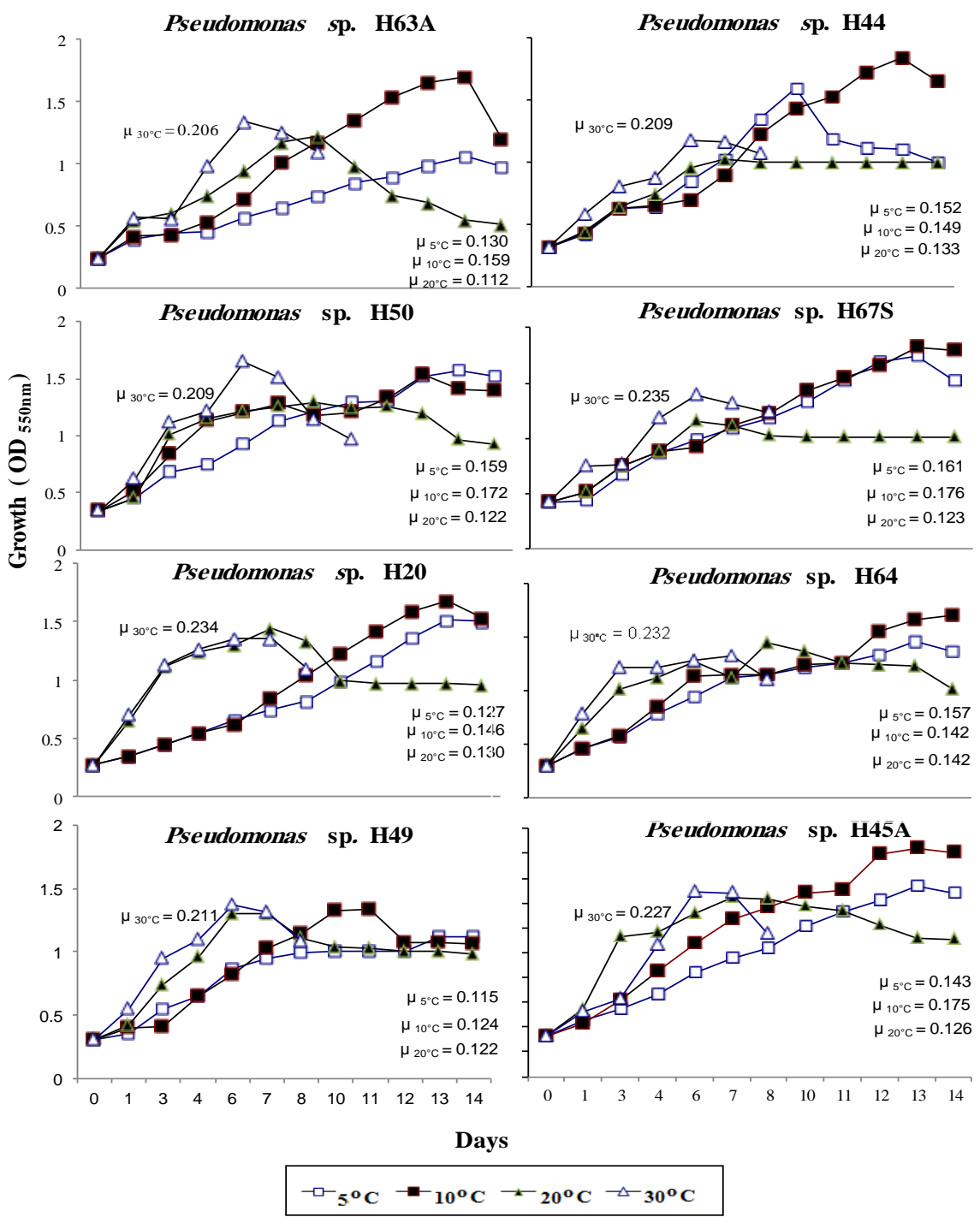

Fig. 1: Growth of Pseudomonas strains on tryptone yeast extract medium at different temperatures (cont.)

\section{Heavy metal accumulation by Pseudomonas strains Minimum inhibitory concentration (MIC)}

The MIC values of each metal against Pseudomonas strains showed that, the resistance to metal ions was species dependent i.e. varied according to strain tested. The highest tolerance was observed with lead ions as all strains grew in presence of 750-800 ppm, for zinc the MICs ranged from 50 to $400 \mathrm{ppm}$, while for nickel they varied from 100 to $400 \mathrm{ppm}$. Also, Pseudomonas strains were resistance to cupper and cadmium (150 to $400 \mathrm{ppm}$ ). The tested Pseudomonas stains were suitable for the multiple metals resistance. The two Pseudomonas strains H67 and H60 were the most resisted strains isolated in this work (Table 5).

Other studies are in good agreement with our data (Ashraf et al., 2007; Rajbanshi, 2008; Selvi et al., 2012). Moreover, Anyanwu and Nwachukwun (2011) reported that some isolates had MIC over $1000 \mu \mathrm{g} / \mathrm{ml}$ against lead. 
Table 5: Minimum inhibitory concentration of heavy metals for Pseudomons strains

\begin{tabular}{llllll}
\hline \multirow{2}{*}{ Strains } & \multicolumn{4}{c}{ Heavy metal concentrations (ppm) } \\
& $\mathbf{Z n}^{\mathbf{2 +}}$ & $\mathbf{N i}^{\mathbf{2 +}}$ & $\mathbf{C u}^{\mathbf{2 +}}$ & $\mathbf{C d}^{\mathbf{2 +}}$ & $\mathbf{P b}^{\mathbf{2 +}}$ \\
\hline Pseudomonas sp. H26S & 400 & 250 & 300 & 250 & 800 \\
Pseudomonassp.H73 & 350 & 350 & 250 & 400 & 800 \\
Pseudomonassp.H69A & 300 & 400 & 250 & 350 & 800 \\
PseudomonasspH20S & 250 & 150 & 200 & 200 & 750 \\
Pseudomonassp. H67 & 400 & 400 & 400 & 250 & 800 \\
Pseudomonassp. H60 & 400 & 400 & 300 & 150 & 800 \\
Pseudomonassp.H63A & 350 & 400 & 350 & 300 & 750 \\
Pseudomonassp. H44 & 300 & 400 & 300 & 200 & 800 \\
Pseudomonassp. H50 & 50 & 250 & 250 & 300 & 800 \\
PseudomonasspH67S & 150 & 200 & 200 & 250 & 800 \\
Pseudomonassp. H20 & 300 & 400 & 200 & 350 & 750 \\
Pseudomonassp. H64 & 50 & 400 & 150 & 300 & 800 \\
Pseudomonassp. H49 & 400 & 250 & 400 & 300 & 800 \\
Pseudomonassp.H45A & 300 & 100 & 250 & 400 & 800 \\
\hline
\end{tabular}

\section{Metal bioaccumulation}

Few publications dealt with the removal of heavy metals by psychrotolerant bacteria Data in Fig. 2 depict that all psychrotolerant Pseudomonas strains were able to accumulate tested metal ions with a variable degree, depending on bacterial strains and metal ion species. In general, lead was the most readily accumulated metal compared to other metal ions. It is worth to mention that Pseudomonas sp. H69A cells exhibited the highest accumulated values to lead and cupper ions (2.95 and $1.837 \mathrm{mg}$ /g wet cells, respectively).Cadmium bioaccumulation was relatively low with respect to the other two metals. Bioaccumulation values ranged from 0.217 to $1.690 \mathrm{mg} / \mathrm{g}$ fresh cells.

Marine bacteria transform, adsorb and accumulate heavy metals in many food chains (De Souza et al., 2006). Shakibaie et al., (2008) and Odokuma and Akponah (2010) reported that Pseudomonas strains were predominant bacteria which could tolerate high concentrations of copper and zinc. Krishna et al., (2012) mentioned that Pseudomonas sp. has high efficiency to accumulate cadmium ions and a high adsorption yield for the treatment of wastewater containing cadmium ions.

\section{Dyes decolorization by Pseudomonas strains}

Data in Fig. 3 depict that all Pseudomonas strains achieved powerfull decolorization activity with tested dyes (fast orange, methanil yellow and acid fast red). The decolorization percentages of the tested dyes by Pseudomonas strains ranged from $33 \%$ to $91 \%$ for fast orange, $5 \%$ to $73 \%$ for methanil yellow and $24 \%$ to $82 \%$ for acid fast red. The maximum decolorization activity was recorded in fast orange. Pseudmonas sp. H26S recorded the highest decolorization percentages (91\%) with fast orange and their biosorption capacity were $4.8 \mathrm{mg} / \mathrm{g}$. whereas, Pseudomonas sp. H63A was more effective in decolorization of methanil yellow with decolorization percentage $65 \%$ and biosorption capacity $3.23 \mathrm{mg} / \mathrm{g}$. Most of the tested isolates recorded low biosorption percentages with acid fast red $(24 \%-57 \%)$, except Pseudomonas sp. H20S recorded high biosorption percentage (82\%) with biosorption capacity reached to $3.7 \mathrm{mg} / \mathrm{g}$. 

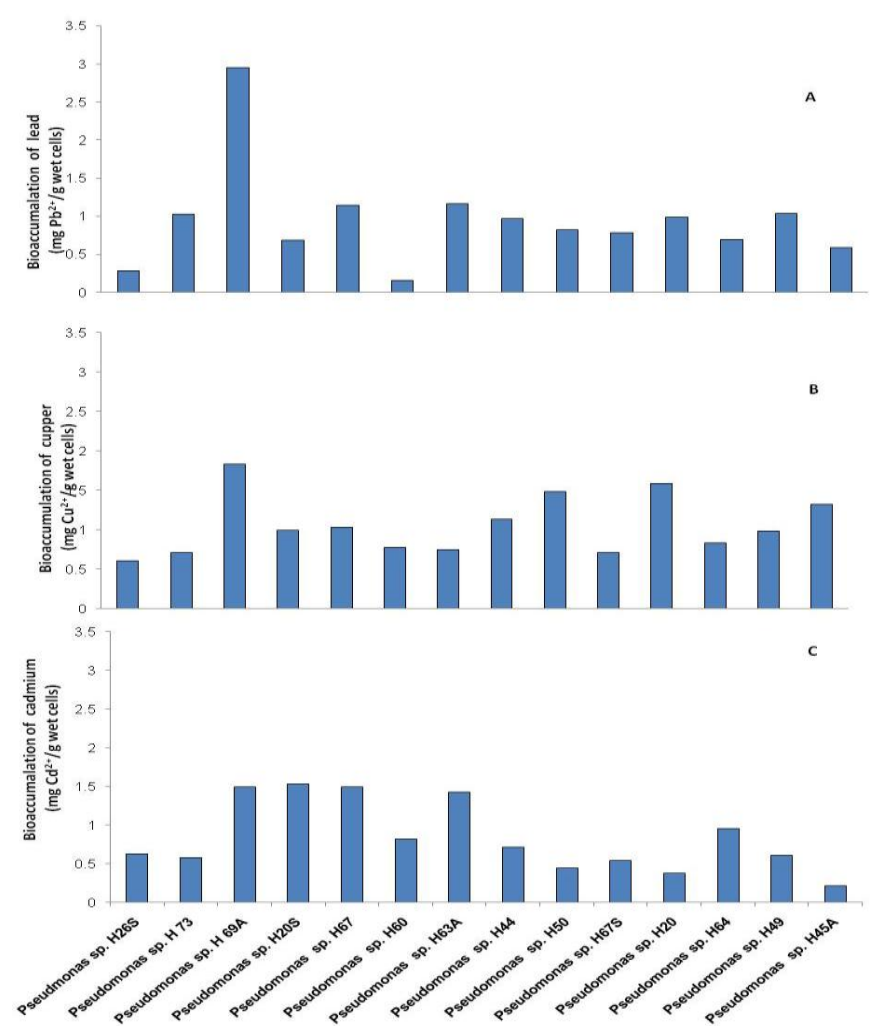

Fig. 2: Bioaccumulation of $\mathrm{Pb}^{2+}, \mathrm{Cu}^{2+}$ and $\mathrm{Cd}^{2+}$ by Pseudomonas strains
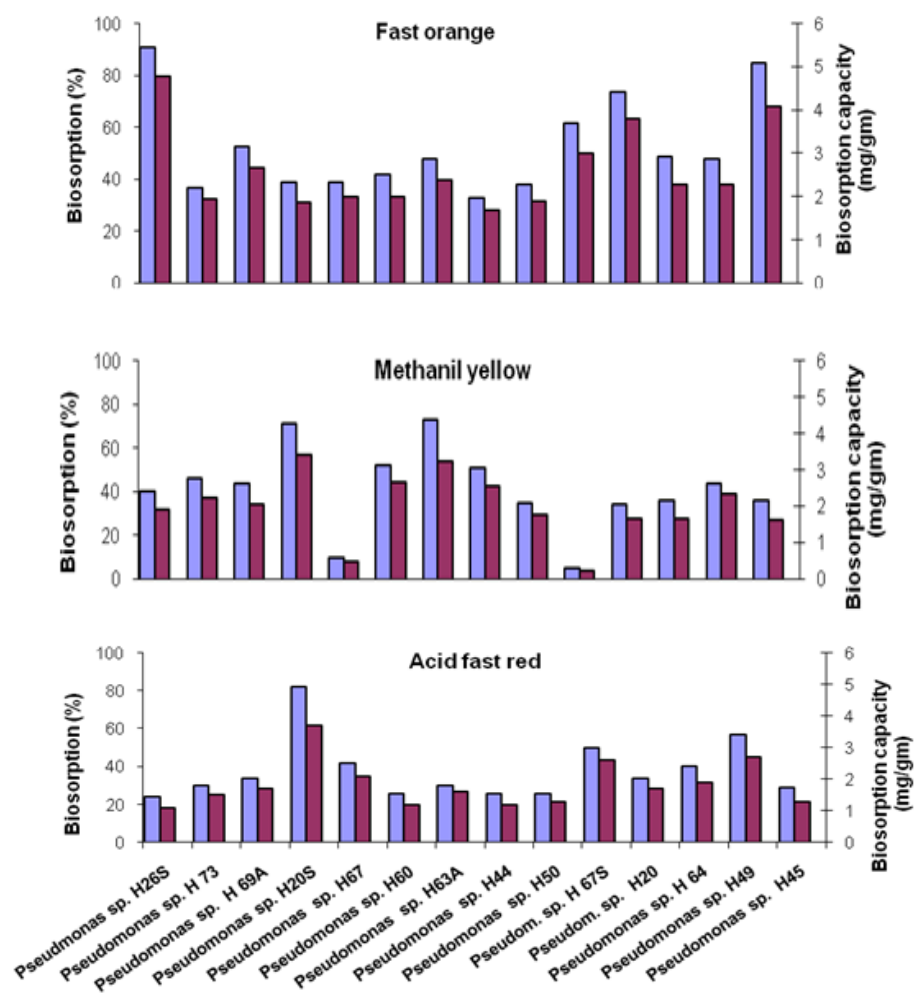

Strains

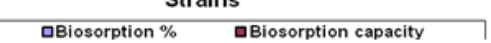

Fig. 3. Decolorization percentage and biosorption efficiency of dye removal by Pseudomonas strains. 
Tom-Sinoy et al., (2011) examined the potential of aerobic mixed culture of Pseudomonas sp. for decolourization of Brilliant Green Malachite Green, Carbol Fuchsin and Crystal Violet dyes. Ponraj et al., (2011) showed that, maximum decolorization efficiency (89 \%) was achieved at $\mathrm{pH} 6.0$ for Pseudomonas sp. Rajamohan and Rajasimman (2013) reported that, the biodegradation studies of dye effluent were performed utilizing Pseudomonas stutzeri in a controlled laboratory environment under anoxic conditions.

\section{CONCLUSION}

Few studies reported the presence of psychrotolerant (cod-adapted bacteria) bacteria outside extremely cold habitats. This paper presents Pseudomonas strains isolated from moderate temperatures marine ecosystem using culture-dependent techniques. It provides important information about the physiological capabilities and phylogenetic analysis of these strains. Moreover, it provides the importance of Pseudomonas strains for bioremediation of different contaminants as heavy metals and azo-dyes.

\section{REFERENCES}

Abd-Elnaby, H.M.; Abou-Elela, G.M. and El-Sersy, N.A. (2011). Cadmium resisting bacteria in Alexandria Eastern Harbor (Egypt) and optimization of cadmium bioaccumulation by Vibrio harveyi. Afr. J. Biotechnol., 10: 3412-3423.

Abd-Elnaby, H.M.; Abou-Elela, G.M.; Ghozlan H.A.; Hussein H. and Sabry S.A. (2016). Characterization and bioremediation potential of marine Psychrobacter species. Egypt. J. Aqua. Res., 42: 193-203.

Anyanwu, C.U. and Nwachukwu, .O.N. (2011). Heavy metal resistance in bacteria isolated from contaminated and uncontaminated soils. Int. J. Res. Chem. Environ. 1:173-178.

Ashraf, R. and Adam, T. (2007). Tested metals and the highest tolerance of bacterial strain. J. Biotecnol., 39: 629- 636.

Azevedo, J. S. N.; Correia, A. and Henriques, I., (2013). Molecular analysis of the diversity of genus Psychrobacter present within a temperate estuary. FEMS Microbiol. Ecol. 84 (3), 451- 460.

Babaeekhou L.; Karshenasan H. and Pishkar L., (2018). Antibiotic resistance in clinical isolates of Pseudomonas aeruginosa: A new viewpoint for antibiotic prescription. Avicenna J. Clinic. Microbiol. Infect., 5(3): 55- 60

Bakermans, C.; Ayala-del-Rio, H.L.; Ponder, M.A.; Vishnivetskaya, T.; Gilichinsky, D.; Thomashow, M.F. and Tiedje, J.M. (2006). Psychrobacter cryohalolentis sp. nov. and Psychrobacter arcticus sp. nov., isolated from Siberian permafrost. Int. J. Syst. Evol. Microbiol., 56: 1285 - 1291.

Bozal, N.; Jesu, M.; Montes, S. and Mercade, E. (2007). Pseudomonas guineae sp. nov., a novel psychrotolerant bacterium from an Antarctic environment. Int. J. Syst. Evol. Microbioly., 57: 2609 - 2612.

De Souza, M. J.; Nair, S.; Loka bharathi, P. A. and Chandramohan, D. (2006). Metal and antibiotic-resistance in psychrotrophic bacteria from Antarctic marine waters. Exotoxicol., 15: 379- 384.

Divya, J.; Ramesh C.; Deep Chandra, S.; Saurabh, K. and Reeta, G. (2019). Impacts of bioinoculants Pseudomonas jesenii MP1 and Rhodococcus qingshengii 
S10107 on Chickpea (Cicer arietinum L.) yield and soil nitrogen status. Pedosphere, 29(3): 388-399.

El-Ahwany, A.M.D. (2008). Decolorization of Acid Fast Red by metabolizing cells of Oenococcus oeni ML34. Worl. J. Microbiol. Biotechnol., 24: 1521-1527.

Feller, G. and Gerday, C. (2003). Psychrophilic enzymes: hot topics in cold adaptation. Nat. Rev. Microbiol., 1: 200 -208.

Fingold, S.M. and Martin, J.W. (1982). Diagnostic microbiology, $6^{\text {th }}$ Bailey and Scottís (Eds) Mosby, C.V. Co. London, UK.

Forbes, B.A.; Sahm, D.H. and Weissfeld, A.S. (1998). Vibrio, Aeromonas, Plesiomonas shigelloides, and Chromobacterium violaceum. In: Bailey and Scott's Diagnostic Microbiology, $10^{\text {th }}$ (Eds). Louis, S.t., Mosby, (Ed.) Inc. 488500.

Hall T.A. (1999). BioEdit: a user- friendly biological sequence alignment editor and analysis program for Windows 95/98/NT. Nucl. Acid. Sympo. Seri., 41: 95-98.

Hill, R.T. and Fenical, W. (2010). Pharmaceuticals from marine natural products: surge or ebb? Curr. Opin. Biotechnol.. 21: 777-779.

Holt, J.G.; Krieg, N.R.; Sneath, P.H.A.; Staley, J.T. and Williams, S.T. (2005). Bergey's Manual of Determinative Bacteriology. In: Garrity G.M. (Ed.), vol.2. Springer, NewYork, USA.

Huston, A. L. (2007). Biotechnological aspects of cold adapted enzymes. In: Psychrophiles: From Biodiversity to Biotechnology. Margesin, R., Schinner, F., Marx, J.C, and Gerday, E. (Eds.), Springer. 347- 364.

Krishna, M.P.; Varghesem, R.; Babu, A.V. and Hatha, A.A. (2012). Bioaccumulation of cadmium by Pseudomonas sp. isolated from metal polluted industrial region. Environ. Res. Engin. Manag., 3: 58- 64.

Kriss, A.E.; Mitskevich, I.N.; Rozanova, E.P. and Osnitskaia, L.K. (1976). Microbiological studies of the Wanda Lake (Antarctica). Microbiology (English translation of Mikrobiologiya). 45: 1075-1081 (in Russian).

Lyudmila, A.; Romanenko, S.P.; Manfred, R.; Anatoly, M.; Lysenko, M.V. and Stackebrand, E. (2002). Psychrobacter submarines sp. nov. and Psychrobacter marincola sp. nov., psychrophilic halophiles from marine environments. Int. J. Sys. Evol. Microbiol., 52: 1291-1297.

Ma, Y.; Wang, L. and Shao, Z. (2006). Pseudomonas, the dominant polycyclic aromatic hydrocarbon-degrading bacteria isolated from Antarctic soils and the role of large plasmids in horizontal gene transfer. Environm. Microbiol., 8: 455465.

Margesin, R.; Neuner, G. and Storey, K.B. (2007). Cold-loving microbes, plants and animals fundamental and applied aspects. Naturwissenschaften. 94: 77- 99.

Mergeay, M.; Nies, D.; Schlegel, H.G.; Gerits, J.; Charles, P. and Van Gijsegem, F. (1985). Alcaligenes eutrophus $\mathrm{CH} 34$ is a facultative chemolithotroph with plasmid-bound resistance to heavy metals. J. Bacteriol., 162: 328- 334.

Odokuma, L.O. and Akponah, E. (2010). Effect of concentration and contact time on heavy metal uptake by three bacterial isolates. J. Environ. Chem. Ecotoxicol., 2: $84-97$. 
Orellana-Saez M.; Pacheco N.; Costa J.I.; Mendez K.N.; Miossec M.J.; Meneses C.; Castro-Nallar E.; Marcoleta, A.E. and Poblete-Castro, I. (2019). In-Depth Genomic and phenotypic characterization of the Antarctic psychrotolerant strain Pseudomonas sp. MPC6 reveals unique metabolic features, plasticity, and biotechnological potential. Frontiers Microbiol., 10:1154

Pang Z.; Raudonis R.; Glick B.; Lin T. and Cheng Z. (2019). Antibiotic resistance in Pseudomonas aeruginosa: mechanisms and alternative therapeutic strategies. Biotechnol. Adv., 37(1):177-192.

Paniker, G.; Aislabie, J. and Bej, A. K. (2006). Analysis of aggregative behavior of Pseudomonas sp. 30-3 isolated from Antarctic Soil. Soil Biol. Biochem., 38: 3152-3157.

Ponraj, M.; Gokila, K. and Vasudeo Zambare, V. (2011). Bacterial decolorization of Textile dye-orange 3R. Int. J. Adv. Biotechnol. Res., 2: 168 -177.

Rajamohan, N. and Rajasimman, M. (2013). Kinetic modeling of dye effluent biodegradation by Pseudomonas Stutzeri. Eng. Technol. Appl. Sci. Res., 3: 387390.

Rajbanshi, A. (2008). Study on heavy metal resistant bacteria in Guheswori sewage treatment plant. Nature, 6: 52 - 57.

Reddy, G.S.N.; Matsumoto, G.I.; Schumann, P.; Stackebrandt, E. and Shivaji, S. (2004). Psychrophilic Pseudomonads from Antarctica: Pseudomonas antarctica sp. nov., Pseudomonas meridiana sp. nov. and Pseudomonas proteolytica sp. nov. Int. J. Syst. Evol. Microbiol., 54: 713 -719.

Sabry, S.A.; Ghozlan, H.A. and Abou- Zeid, D.M. (1997). Metal tolerance and antibiotic resistance patterns of a bacterial population isolated from sea water. J. Appl. Microbiol., 82: 245-252.

Salvino, D.; Tony, C.; Jean-Claude, M.; Georges, F. and Charles, G. (2006). Psychrophilic microorganisms: challenges for life. EMBO Reports., 7: 385-393.

Selvi, A.T.; Anjugam, E.; Archana-Devi, R.; Madhan, B.; Kannappan, S. and Chandrasekaran, B. (2012). Isolation and characterization of bacteria from tunnery effluent treatement plant and their tolerance to heavy metals and antibiotics. Asian J. Exp. Biolog. Sci., 3: 34 - 41.

Shakibaie, M.R.; Khosravan, A.; Frahmand, A. and Zare, S. (2008). Application of metal resistant bacteria by mutation enhancment technique for bioremediation of copper and zinc from industrial wastes. Iranian J. Environ. Heal. Sci. Eng., 5: $251-256$.

Shimshon, B. and Ritar, C. (2005) Oceans and Health pathogens in the marine environment. Spring.

Simon, C. and Daniel, R. (2009). Achievements and new knowledge unraveled by metagenomic approaches. Appl. Microbiol. Biotechnol., 85: 265-276.

Tom-Sinoy, E.S.; Mohan, D.A. and Shaikh, H. (2011). Biodegradation of textile dyes by Pseudomonas species and E.Coli. $2^{\text {nd }}$ Edition. VSRD-TNTJ. 2: 238-248.

Trotsenko, Y.A. and Khmelenina, V.N. (2005). Aerobic methanotrophic bacteria of cold ecosystems. FEMS Microbiol. Ecol., 53: 15 - 26.

Vásquez-Ponce F.; Higuera-Llantén S.; Pavlov M.S. and Marshall S.H. (2018). Phylogenetic MLSA and phenotypic analysis identification of three probable novel Pseudomonas species isolated on King George Island, South Shetland, Antarctica. Environ. Microbiol., 49: 695 - 02

Yang, S.; Sun, W; Tang, C.; Jin, L.; Zhang, F. and Li, Z. (2013). Phylogenetic diversity of actinobacteria associated with soft coral Alcyonium gracllimum and 
stony coral Tubastraea coccinea in the East China Sea. Microbiol. Ecolog. 66:189 -199.

Yarzabal L.; Monserrate3 L.; Buela L. and Chica E., (2019). Antarctic Pseudomonas spp. promote wheat germination and growth at low temperatures. Polar Biology, https://doi.org/10.1007/s00300-018-2374-6.

Zhang C. and Kim S. (2010). Research and Application of Marine Microbial Enzymes: Status and Prospects. Mar. Drugs, 8(6): 1920 -1934.

Zhang, X.Y.; Bao, J.; He, F.; Xu, X.Y.; Wang, G.H. and Qi, S.H. (2013). Diversity and antibacterial activity of culturable actinobacteria isolated from five species of the South China Sea gorgonian corals. World J. Microbiol. Biotechnol., 29: 1107- 1116. 